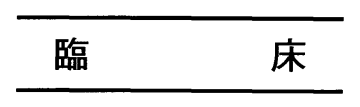

外耳道結 節性筋膜炎 例

菅原 一真・今手 祐二・下郡 博明

清水 徳雄・中野 智子・山下 裕司

\title{
Nodular Fasciitis of the External Auditory Canal
}

\author{
Kazuma Sugahara, Yuji Imate, Hiroaki Shimogori, \\ Norio Shimizu, Tomoko Nakano and Hiroshi Yamashita \\ (Yamaguchi University)
}

\begin{abstract}
We report a rare case of nodular fasciitis in a 56-year-old female with a soft nodule in the external auditory canal. The nodule was treated by surgical excision, and the pathological diagnosis was nodular fasciitis. There has been no sign of recurrence. This is the first report in Japan of nodular fasciitis in the external auditory canal.
\end{abstract}

Key words : nodular fasciitis, external auditory canal, surgical excision

はじめに

結節性筋膜炎は間葉型の細胞, 特に線維芽細胞, 組織 球が反応性に増殖して生じる疾患である.1955年 Konwaler $ら^{1)}$ が初めて報告して以来，多数報告されている が，その多くは上下肢，体幹に発生し，頭頸部領域では 比較的まれである.今回われわれは外耳道に発生し, 保 存的治療では改善しないため, 形成術を要した結節性筋 膜炎の症例を経験したので報告する。

\section{症例}

患者 : 56 歳, 女性.

主訴：左外耳道腫瘤, 左耳痛.

既往歴：6 年前に左外耳道裂傷, 耳出血の既往がある. 家族歴 : 特記すべきことなし.

現病歴 : 以前より, 外耳道清掃の癖があり, 時には両 耳出血を認めたが放置することが多かった. 平成 10 年 3 月頃外耳道の清掃時に左耳出血を認めたが放置していた。 4 月 20 日頃左外耳道腫瘤を自覚し, 徐々に増大した. 疼
痛が出現してきたため, 平成10年 4 月 30 日近医耳鼻咽喉 科を受診し，同日，当科を紹介された.

局所所見 : 左外耳道入口部に $24 \times 19 \mathrm{~mm}$ の暗赤色, 弾性軟の腫瘤を認め，外耳道は閉塞していた(図 $1 \mathrm{a})$. 著明な疼痛, 圧痛を伴い, 可動性は不良であった. 外耳 道内より粘膿性の耳漏を認めた。

術前 CT 所見 (図 2)：左外耳道入口部に軟部組織陰影 を認め, 外耳道は閉塞していた。また，鼓室内にも軟部 陰影を認めた。

病理所見(図 3 ): 初診時, 外来で行った生検による病 理組織検查で結節性筋膜炎と診断された。

経過: 初診日に入院し, 生検の結果が明らかとなるま での 6 日間, 外耳道炎として FMOX $2 \mathrm{~g}$ / 日を点滴静注 したが, 腫瘤は増大傾向を示し(図 $1 \mathrm{~b})$, 疼痛も増強し たため， 5 月 8 日全身麻酔下に外耳道腫瘤摘出術を施行 した. 外耳道入口部の腫瘤周囲に皮切を置き, 外耳道軟 骨を含め切除を試みた。腫瘤は周囲との境界は不明瞭で, 明らかに軟骨を越兄前下方の耳下腺内へ進展していたた 


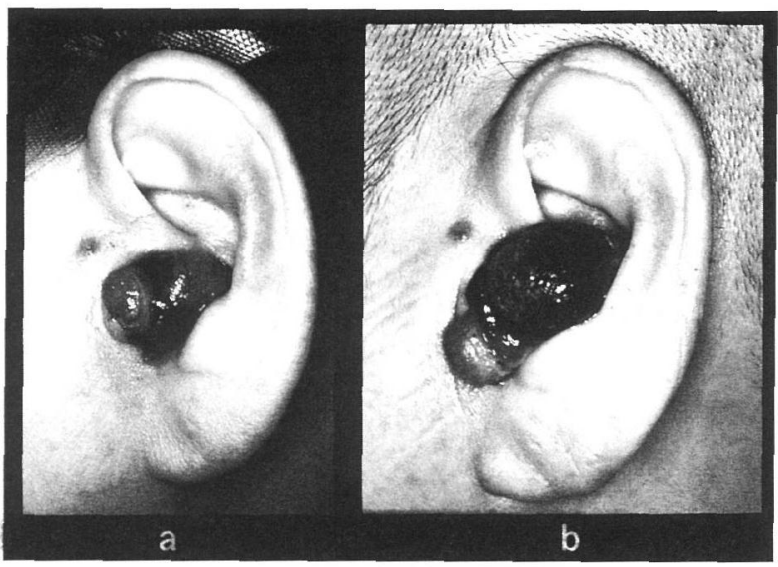

図 $1 \mathrm{a}:$ 耳介所見

左外耳道入口部に暗赤色の腫瘤学認め，外耳道は閉 塞していた(平成10年 4 月30日).

b : 術前耳介所見

腫瘤は増大し，外耳道より突出している(平成10年 5月 7 日).

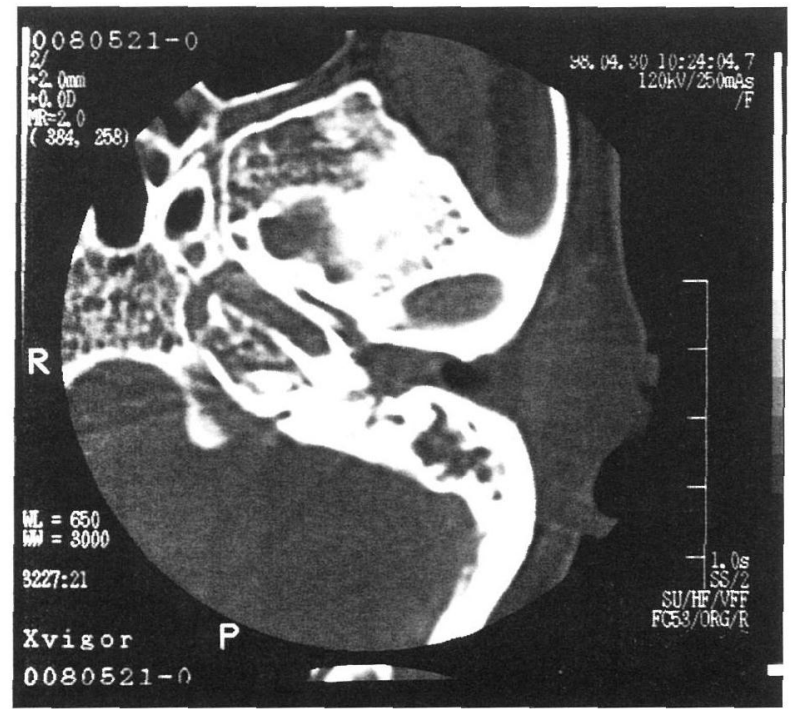

図 2 術前 CT (軸位断)

左外耳道入口部と鼓室内に軟部組織陰影を認める(平成 10年 4 月 30 日).

め, 通常の耳下腺手術に準じ, 耳前部より耳下部へ切開 を延長した。腫瘤は耳下腺浅葉内へ進展していたため, 耳下腺浅葉の一部を腫瘤に付けて切除した(図 4). 顔面 神経は確認保存した。鼓室内は貯留液を認めるのみで あったため，操作は加壳なかった，切除によって生じた 軟骨部外耳道前下壁から耳介にかけての皮虚欠損は，耳

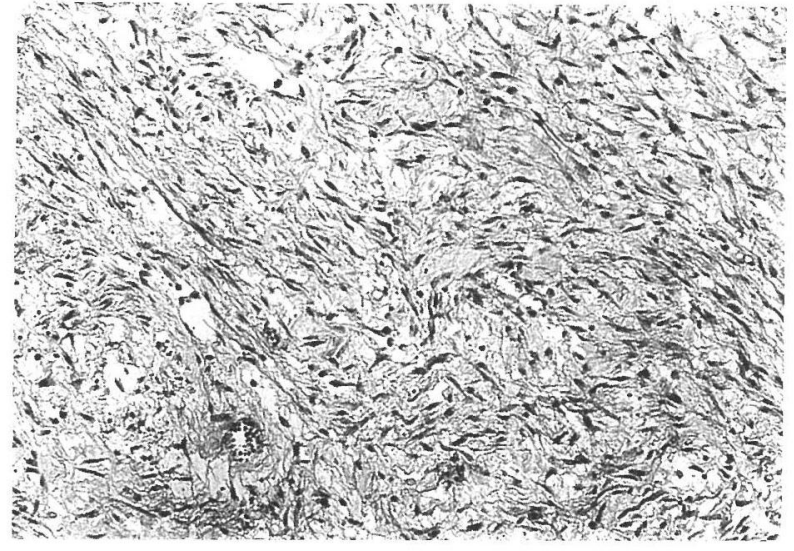

図 3 病理所見 $(\mathrm{HE}$ 染色, $\times 200)$

粘液様物質を背景に，紡錘形の線維芽細胞様の細胞が浸 潤，増殖している。異形性は認めず，結節性筋膜炎と診 断された。

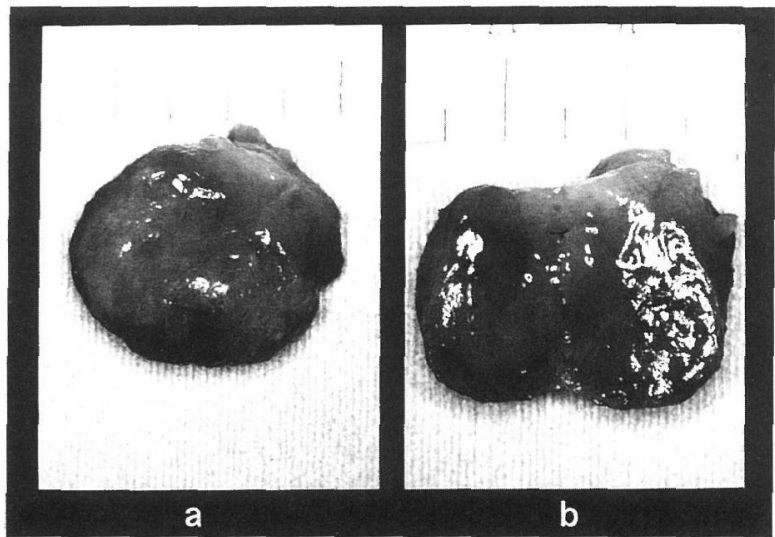

図 4 摘出標本

$\mathrm{a}$ : 外観 $\mathrm{b}$ : 割面

摘出標本は暗赤色で軟性弾であり，明らかな被膜はなかっ た．割面を入れると，充害性で比較的均一であった。

後部に $20 \times 40 \mathrm{~mm}$ の有茥皮弁を作成し，これを耳介前 部から外耳道内に移動して再建を行った(図 5 )。耳介が 後方に育引されない様，耳垂の付着部を切離した。再発 がないこと䒚確認し，5月29日退院した。切離した耳垂 は，再入院の上，11月11日皮弁上に縫合，固定した。こ の結果，外観上，患者の満足を得ることができた。退院 後, 当科外来で経過観察中であるが，平成11年12月 1 日 までに再発を認めていない。 


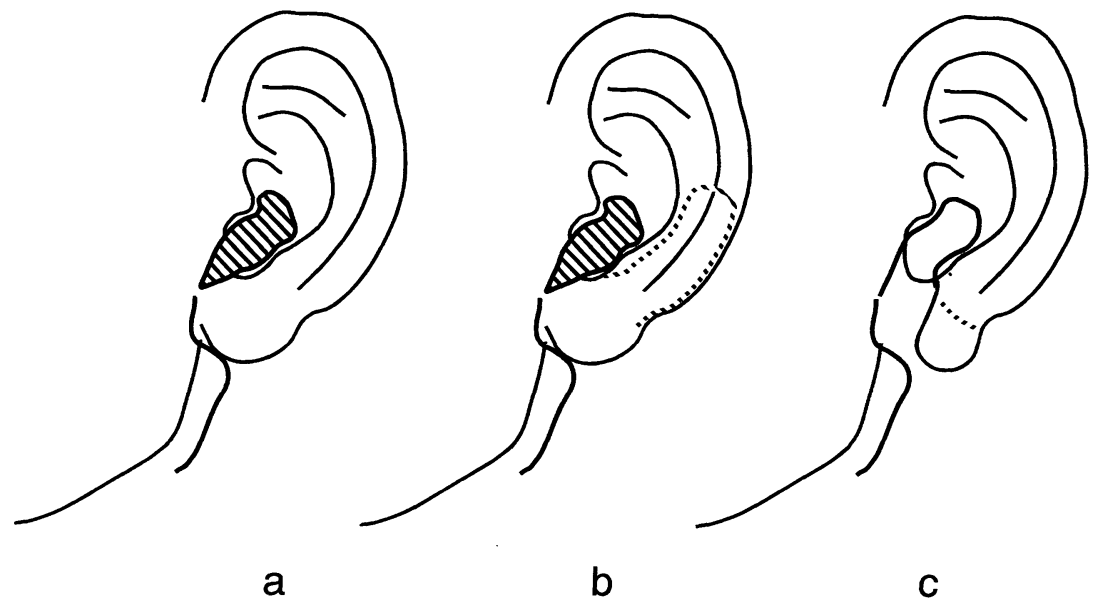

図 5 手術所見

a : 軟骨部外耳道前下壁から外耳道入口部に生じた皮虐欠損の範囲を斜線 で示す。

b : 耳後部に $20 \times 40 \mathrm{~mm}$ の皮弁を作成した.

c：埴の一部を切離し，耳後部に作成した皮弁を用い，横転皮弁法で，

耳前部へ転位し，皮膚欠損部を被覆再建した。

考察

結節性筋膜炎は，1955年 Konwaler ら ${ }^{1)}$ が初めて報告 した疾患である．皮下に出現した後，急速に増大し，疼 痛を伴う例があることから，臨床的には悪性腫瘍を疑わ れる．生検を行われる例が多いが，実際は炎症性の良性 疾患である．好発年龄は20〜 50歳で，性差はわずかに男 性に多いとされる2). 確定診断は病理組織学的に決定さ れる．鑑別診断として神経線維腫，神経鞘腫，線維組織 球腫, 線維腫症, 線維肉腫等があるが, 周辺組織への浸 潤性の線維腫様増殖，幼若な線維芽細胞の増殖と核分裂 像, 毛細血管の増殖と赤血球の管外溢出, 粘液様変性, 多核巨細胞の出現，リンパ球と組織球を主体とした炎症 性細胞浸潤の 6 項目の所見を種々の程度に認めることで 診断され，特殊染色の必要はないとされる33.

本疾患の発症原因は不明であるが，組織学的所見が創 傷治癒過程認めるものと同一であることから，外傷が 誘因とする説4) がある. 本症例は以前より外耳道損傷を 繰り返している既往があり，臨床経過からこれが誘因と

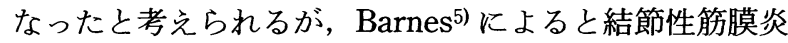
の報告例の中で外傷の既往があるものが $10 \%$ 程度にすぎ ないとしている. 他にホルモンの関与を重視する説6), 組織の老化が関与するとする説などがあるが，いまだ定 説が得られていない。
発生部位：全身のあらゆる部位より発生する可能性が あるが，上下肢に多いとされ，頭頸部領域には $6.8 \%$ と 比較的少ない7). 頭頸部領域では顔面，頸部の皮下にあ る浅在筋膜より発生することが多(18)。われわれの渉搅 し兊た範囲では，これまでに外耳道での報告例は Cynthia $5^{9)}$ とAnton ら 10)の 2 例のみであり，本症例はき わめてまれな症例と考兄られた。

治療：良性疾患であることから，局所の切除で十分で ある. Majumdar ${ }^{8)}$ は経過観察を行い, 自然治瘉した症 例を報告しているが，実際には腫瘤の増大の速度が速く， 進行を早期に抑制するためにも切除されることが多い． 本症例に打いても, 診断確定の後, 抗生剂を併用し経過 観察したが，腫瘤が急速に増大し，疼痛と美容のため患 者が早期の切除を希望したことと，外耳道深部に悪性腫 瘍が潜在している可能性を除外できなかったために，外 科的切除を行った. 結果的には, 術後の病理組織学的診 断は術前診断と同じ結節性筋膜炎であったが，炎症の進 行を抑止することができた. 病変の切除後には, 外耳道 内，外耳道入口部，耳下部に広範な皮膚欠損をきたした。 外耳道の再建方法はこれまでにさまざまな方法が報告さ れている11) 14)が，本症例では，広範な皮膚欠損を被覆 するため比較的面積の大さい皮弁が必要であったこと， 耳下部といら外観に関係する部位であるため分層皮膚移 
植が使用しにくいことより，耳後部に皮弁を作成し，再 建に用いた．皮弁の血流を良好に保つため二期的に再建 し，良好な結果を得た。

\section{結 語}

外耳道に発生した結節性筋膜炎の 1 例を報告した。外 耳道の発生は報告例が少なく、まれな症例と考光た。形 成術を施行し良好な結果を得た。

\section{参考文献}

1) Konwaler BE, Keasbey L and Kaplan L : Subcutaneous pseudosarcomatous fibromatosis (fasciitis). Am J Clin Pathol 25 : 241 252, 1955.

2) Zuber TJ and Finley JL : Nodular fasciitis. South Med J $87: 842 \sim 844,1994$.

3 ）川田陽弘, 増谷 衛: 結節性筋膜炎. 皮膚臨床 $11: 352$, 1969.

4) Soule EH : Prolifertive (nodular) fasciitis. Arch Pathol $73: 437 \sim 444,1962$.

$5)$ Barnes L : Nodular fasciitis. Surgical Pathology of the Head and Neck, vol 1 (ed by Barnes L). pp 758 762, Marcel Dekker, New York, 1985.

6) Kern WH : Prolifertive myositis; pseudosarcomatous reaction to injury, a report of seven cases. Arch Pathol $69: 209 \sim 216,1960$.

7 ）東 英二, 朝倉光司 : 頸部に発生した Nodular fasciitis の
1 例. 耳鼻 $31: 69 \sim 72,1985$.

8 ) Majumdar B : Spontaneously regressing nodular fasciitis of the neck. J Laryngol Otol $97: 973 \sim 977,1983$.

9 ) Cynthia GC, Edward ED, Bradley PP, et al : Cranial fasciitis presenting as an external auditory canal mass. Arch Otolaryngol Head Neck Surg 123 : 223 225, 1997.

10) Anton GCM, Kenneth JV, Sam EK, et al : Nodular fasciitis arising in the external canal. Otolaryngol Head Neck Surg $120: 591 \sim 592,1999$.

11）関谷 透, 田中宗昭, 三谷暢広, 他: 外傷性外耳道閉鎖症 -4 症例の検討と手術法の選択一. 耳喉 48: 901 907, 1976.

12）大上研二, 関谷 透, 下郡博明 : 外耳道腫瘤の 3 症例 耳甲介腔有茎皮弁移植術について一。臨床耳科 $16: 73 \sim$ 77, 1989.

13）下郡博明, 菅原一真, 増満洋一, 他: 当科飞淤ける後天泩 外耳道狭窄, 閉塞症例一その手術手技について一. 耳喉 頭頸 $71: 549 \sim 552,1999$.

14）菅原一真, 下郡博明, 增満洋一, 他: 鼓膜形成術後に発生 した外耳道基底細胞上皮腫例. 耳喉頭頸 $71: 593 \sim 596$, 1999.

$$
\left(\begin{array}{l}
\text { 原稿受付 : 平成 } 11 \text { 年 } 12 \text { 月 } 16 \text { 日 } \\
\text { 原稿採択 : 平成 } 12 \text { 年 } 1 \text { 月 } 19 \text { 日 } \\
\text { 別刷請求先 : 菅原一真 } \\
\text { ₹755- } 8505 \text { 宇部市南小串 } 1-1-1 \\
\text { 山口大学医学部耳鼻咽喉科学教室 }
\end{array}\right)
$$

